\title{
Profil Protein Escherichia coli Hasil Inaktivasi Iradiasi Gamma Sebagai Bahan Vaksin Mastitis
}

\author{
${ }^{1}$ S. Hermanto*, ${ }^{2}$ I. Sugoro, ${ }^{1}$ Ikmalia \\ ${ }^{1}$ Program Studi Kimia FST UIN Syraif Hidayatullah Jakarta \\ ${ }^{2}$ Pusat Aplikasi Tenaga Isotop dan Radiasi - BATAN \\ Shmt75@yahoo.com
}

\begin{abstract}
Abstrak
Penelitian ini bertujuan untuk mengetahui profil protein Escherichia coli hasil iradiasi gamma sebagai bahan vaksin mastitis inaktif. Kultur sel $\left(10^{8} \mathrm{sel} / \mathrm{ml}\right)$ diinaktivasi dengan dosis radiasi sebesar 600, 700, 800, 900 dan 1000 Gy. Kultur sel dianalisis kandungan protein intraselular dan ekstraselular dengan metode Lowry. Profil protein dianalisis dengan menggunakan SDSPAGE dengan konsentrasi gel 10\% dan standar berat molekul kisaran $10-220 \mathrm{kDa}$. Hasil percobaan menunjukkan bahwa tidak terjadi perubahan kadar protein intraselular dan ekstraselular secara signifikan dengan semakin tingginya dosis iradiasi, demikian pula dengan jumlah pita protein, tetapi intensitas setiap pita menunjukkan adanya perbedaan. Perbedaan intensitas protein tertinggi terjadi pada dosis 900 dan 1000 Gy. Hal ini menunjukkan bahwa iradiasi gamma mampu menginaktivasi sel bakteri tetapi tidak merusak protein secara total sebagai salah satu bahan antigen vaksin.
\end{abstract}

Kata kunci : Vaksin, Protein, Escherichia coli, dan iradiasi gamma

\begin{abstract}
The experiment has been conducted to study the profile of Escherichia coli protein which was irradiated by gamma rays as inactive mastitis vaccine. Cells culture $\left(10^{8}\right.$ cells $\left./ \mathrm{ml}\right)$ was irradiated with doses 600, 700, 800, 900 and $1000 \mathrm{~Gy}$. The cell culture was analyzed for total intracellular and extracellular protein by Lowry method. The protein profile was analyzed by SDS-PAGE with $10 \%$ gel concentration and standard of molecular weight was $10-220 \mathrm{kDa}$. The results showed that the total intracellular and extracellular protein unaffected significantly with increasing of doses and so do the protein bands, but the intensity of bands was different. The highest intensity occurred on doses 900 and $1000 \mathrm{~Gy}$. This result showed that the gamma irradiated could be inactivated the bacteria cell but couldn't change the protein totally as one of vaccine antigen.
\end{abstract}

Key words : Vaccine, protein, Escherichia coli and gamma irradiated.

\section{PENDUHULUAN}

Susu merupakan komoditas utama pada usaha ternak sapi perah rakyat. Produksi susu dapat terganggu apabila kondisi ambing (kelenjar susu) bagian dalam dari susu sapi perah mengalami peradangan akibat infeksi oleh mikroba yang dikenal sebagai mastitis. Ada 3 faktor penyebab yang mempermudah terjadinya mastitis, yaitu kondisi sapi sebagai inang, kondisi lingkungan yang buruk dan mikroorganisme sebagai agen penyebab penyakit (Ikmalia, 2008).

Penyakit mastitis dapat disebabkan oleh bakteri coliform, seperti Escherichia coli, Klebsiella spp., dan masih banyak lagi. Selama ini pengobatan penyakit mastitis banyak dilakukan melalui pemberian antibiotik yang dampaknya bisa menimbulkan resitensi pada mikroba dan adanya residu pada susu. Dengan demikian perlu dicari alternatif lainnya untuk mencegah penyakit tersebut. Salah satu alternatif pencegahan penyakit mastitis yang sedang dikembangkan saat ini adalah melalui pemberian vaksin. Vaksin digunakan untuk mencegah masuknya mikroorganisme patogen yang merugikan, sehingga cara ini banyak 
digunakan oleh para peternak sapi (Ruegg P., 2001).

Sampai saat ini, sebagian besar vaksin masih diimpor dengan kisaran pasar $60-70$ $\%$. Oleh karena itu upaya pengembangan bahan vaksin di dalam negeri memiliki nilai strategis dan peluang bisnis. Ketergantungan akan vaksin impor dapat berakibat pada menurunnya cadangan devisa negara dan juga dapat memungkinkan masuknya penyakit hewan melalui kontaminasi agen penyakit pada vaksin yang diimpor. Hal lebih berbahaya lagi adalah timbulnya efek mutasi pada vaksin aktif yang dapat mengakibatkan terjadinya penyakit baru (Tetriana dan Sugoro, 2007).

Vaksin dapat diperoleh dengan cara konvensional, baik secara kimia maupun pemanasan. Alternatif lainnya dengan menggunakan radiasi sinar gamma untuk menginaktifasi sel bakteri. Metode inaktivasi dengan sinar gamma memiliki efektifitas dalam peningkatan respon imun dibandingkan dengan teknik konvensional, seperti pemanasan (Arifin, M., 2006).

Dalam percobaan ini digunakan bakteri E. coli hasil isolasi dari susu sapi perah yang terinfeksi mastitis. Percobaan sebelumnya menunjukkan, bahwa isolat bakteri ini dapat diinaktivasi dengan radiasi gamma pada kisaran dosis 600 - 1000 Gy (Tetriana dan Sugoro, 2007). Salah satu bagian sel bakteri yang berperan sebagai faktor virulensi adalah protein (Gibco, 2000). Melalui teknik iradiasi ini diharapkan bakteri $E$. coli sebagai organisme patogen penyebab penyakit mastitis dapat dilemahkan, sedangkan protein yang berperan sebagai faktor virulensinya diharapkan tetap utuh. Atas dasar hal tersebut maka penelitian ini dilakukan untuk mengetahui kandungan dan profil protein bakteri $E$. coli hasil inaktivasi sinar gamma sebagai bahan vaksin mastitis inaktif.

\section{METODE PENELITIAN}

\section{Bahan dan Alat}

Isolat bakteri E. coli S1 diperoleh dari susu sapi lokal yang terinfeksi mastitis dan sudah dikultivasi di Laboratorium Nutrisi, Kesehatan dan Reproduksi ternak, Pusat Aplikasi Tenaga Isotop dan Radiasi (PATIR) BATAN Pasar Jumat Jakarta Selatan.
Bahan yang digunakan terdiri dari Media NB (Nutrient Broth), Media NA (Nutrient Agar), larutan Akrilamid 10\%, buffer elektroforesis TEMED (N,N,N',N'Tetramethylethylenediamine), Ammonium persulfat dan commasie briliant blue R-250 untuk staining protein.

Peralatan yang digunakan terdiri dari Sonikator Branson 2210, autoclave, Spektrofotometer Genesys, Sentrifuge Hitachi CR21G II, Gamma Chamber 4000A, Mini protean Gel Electrophoresis, Atto.

\section{Iradiasi Escherichia coli dengan Sinar Gamma}

Kultur pada fase mid log disentrifugasi $10.000 \mathrm{rpm}$ dan dibilas dengan aquades steril sebanyak 2 kali. Supernatan yang diperoleh diencerkan hingga diperoleh jumlah sel $10^{8}$ $\mathrm{sel} / \mathrm{ml}$ dan ditempatkan di dalam vial gelas sebanyak $10 \mathrm{ml}$. Selanjutnya diiradiasi gamma dengan dosis 600, 700, 800, 900 dan 1000 Gy di Iradiator Gamma Chamber 4.000 A dengan laju dosis 108,959 krad/jam (Machi, S., 2002). Kultur hasil iradiasi kemudian dihitung jumlah selnya dengan metode droptest untuk uji inaktivasi (Hall, E.J., 1994).

\section{Pengukuran Protein Sel E. coli dengan Metode Lowry}

Kultur hasil iradiasi diukur kandungan protein ekstraselular dan intraselularnya. Untuk mengetahui kandungan protein ekstraselular langsung menggunakan kultur hasil iradiasi, sedangkan untuk protein intraselular dipecah terlebih dahulu dengan melarutkan kultur hasil iradiasi ke dalam aseton (1: 1) dan disonifikasi selama 15 menit. $1 \mathrm{ml}$ sampel ditambahkan ke dalam 5 ml larutan Lowry I dan dibiarkan selama 10 menit. Selanjutnya ditambahkan $0,5 \mathrm{ml}$ larutan Lowry II dan dibiarkan selama 30 menit. Absorbansi larutan diukur dengan spektrofotometer pada panjang gelombang 700 nm (Murray, P., 1990).

\section{Karakteristik Profil Protein Bakteri E. coli}

Profil protein dianalisis dengan menggunakan metode elektroforesis satu dimensi SDS-PAGE dengan sistem buffer Laemmli dan konsentrasi gel poliakrilamid 10\% (Hames B.D., 1998). Kultur hasil hasil iradiasi sebanyak $20 \mu \mathrm{l}$ ditambahkan $10 \mu \mathrm{l}$ 
aseton dan disonikasi selama 15 menit. Kemudian ditambahkan buffer sampel Laemli sebanyak $20 \mu \mathrm{l}$ dan dipanaskan selama 15 menit dalam air mendidih. Setelah itu disentrifugasi pada $8000 \mathrm{rpm}$ selama 5 menit. Sebanyak $5 \mu$ filtrat sampel dan standar dimasukkan ke dalam kolom gel dan dielektroforesis pada kondisi $200 \mathrm{~V}$ dan 40 $\mathrm{mA}$ selama \pm 100 menit. Gel diwarnai dengan commassie $R-250$ (BioRad) selama 1 jam lalu didestaining dengan destaining solution commassie R-250 (BioRad) selama 24 jam. Hasil yang diperoleh dianalisis lebih lanjut untuk menentukan jumlah dan profil protein dengan menggunakan program Lab Image.

\section{HASIL DAN PEMBAHASAN}

\section{Inaktivasi sel $E$. coli dengan iradiasi Sinar Gamma}

Hasil irradiasi sel E. coli dengan sinar gamma yang dilakukan pada dosis 0 Gy 1000 Gy dengan laju dosis 1089,59 Gy/jam menunjukkan terjadinya penurunan jumlah sel yang sebanding dengan meningkatnya dosis irradiasi (Gambar 1). Dosis optimum irradiasi yang diperlukan untuk menginaktivasi sel $E$. coli berkisar antara $800-1000 \mathrm{~Gy}$.

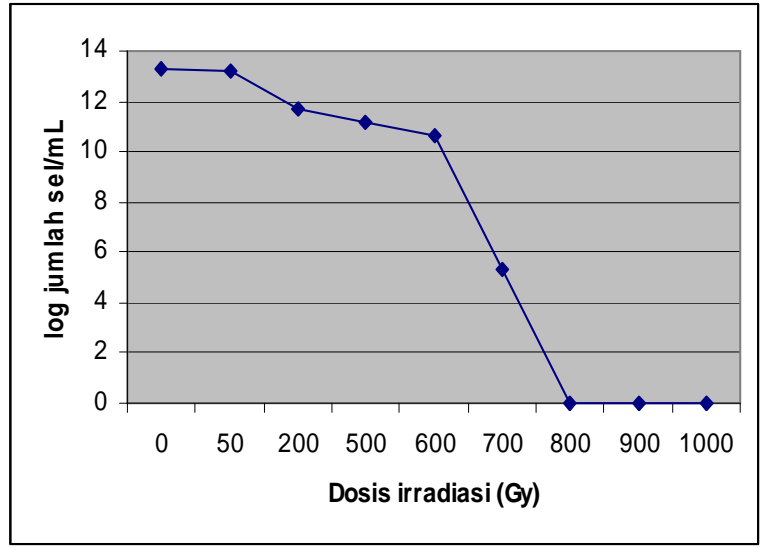

Gambar 1. Hasil irradiasi sinar gamma terhadap sel E. coli.

Kondisi inaktif terjadi karena terganggunya metabolisme sel yang menyebabkan sel bakteri tidak mampu bereplikasi akibat adanya efek irradiasi. Hal ini kemungkinan terjadi karena irradiasi dapat menyebabkan kerusakan genetik atau rusaknya struktur DNA/kromosom sel bakteri (Ramamoorthy, S., 2006).

\section{Perubahan Kadar Protein}

Iradiasi dengan dosis berbeda pada kultur bakteri menunjukkan adanya perubahan kadar protein total, ekstra dan intraselular, tetapi tidak menimbulkan kerusakan yang signifikan (Gambar 2). Kadar protein tertinggi terjadi pada dosis iradiasi $600 \mathrm{~Gy}$, dengan jumlah protein total $325 \mathrm{mg} / \mathrm{mL}$, sedangkan yang terendah terjadi pada dosis iradiasi 800 Gy dengan kadar protein $253 \mathrm{mg} / \mathrm{mL}$. Perbedaan kadar protein ini diduga karena dosis yang diberikan tidak terlalu besar dan sifat acak dari kerusakan yang ditimbulkan oleh iradiasi sinar gamma yang dapat mempengaruhi level ekspresi protein baik intraseluler maupun ekstraseluler (Benneth, C., et.al., 2002).

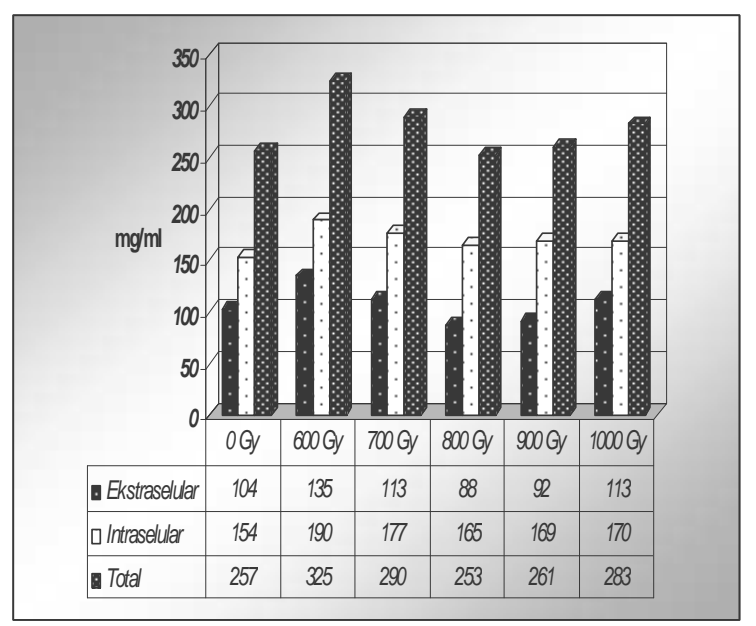

Gambar 2. Kandungan protein bakteri E.coli.

Suatu materi hidup seperti sel, bila terkena sinar gamma akan mengalami kerusakan secara langsung atau tidak langsung. Efek langsung adalah terjadinya pemutusan ikatan senyawa-senyawa penyusun sel. Efek tidak langsung terjadi karena materi sel terbanyak adalah air yang apabila terkena sinar gamma akan mengalami hidrolisis dan menghasilkan radikal bebas. Radikal bebas inilah yang akan mempengaruhi sistem metabolisme atau menyebabkan kerusakan materi sel (Hall. E.J, 1994).

\section{Profil protein E.coli Inaktif}

Hasil elektroforesis protein E.coli inaktif menunjukkan pola dan intensitas yang relatif tidak berbeda (Gambar 3). Hal ini berarti bahwa iradiasi gamma tidak merusak total 
antigen protein dan memperkuat hasil analisis kandungan protein sebelumnya. Protein dari sel E.coli yang diiradiasi dan tidak diiradiasi memiliki jumlah pita sebanyak 35 buah dengan berat molekul berkisar $15-220 \mathrm{kDa}$.

Intensitas yang nyata berbeda, terjadi pada dosis 600, 700, 900 dan 1000 Gy, sedangkan pada dosis 800 Gy tidak tampak perbedaan nyata. Perubahan intensitas (konsentrasi) protein dapat disebabkan oleh kerusakan yang diakibatkan oleh iradiasi sinar gamma, baik pada struktur maupun ikatan proteinnya. Perubahan struktur dapat diakibatkan oleh denaturasi maupun degradasi protein (Sanakayala, N., et.al., 2005).

Penelitian yang dilakukan oleh Vuckovic M. 2005, menyebutkan bahwa pengaruh irradiasi sinar gamma terhadap stabilitas protein tidak terlalu signifikan pada dosis irradiasi di bawah 1000 Gy. Kerusakan protein pada dosis ini hanya terjadi pada struktur natif yang akan terdenaturasi akibat pengaruh energi irradiasi. Namun demikian pada dosis yang lebih tinggi ( di atas $2000 \mathrm{~Gy}$ ) protein akan terdegradasi dengan munculnya fragmen-fragmen yang lebih pendek akibat terputusnya ikatan peptida (Vuckocic M., 2005).

\section{K 600Gy 700Gy 800Gy 900Gy 1000Gy M}

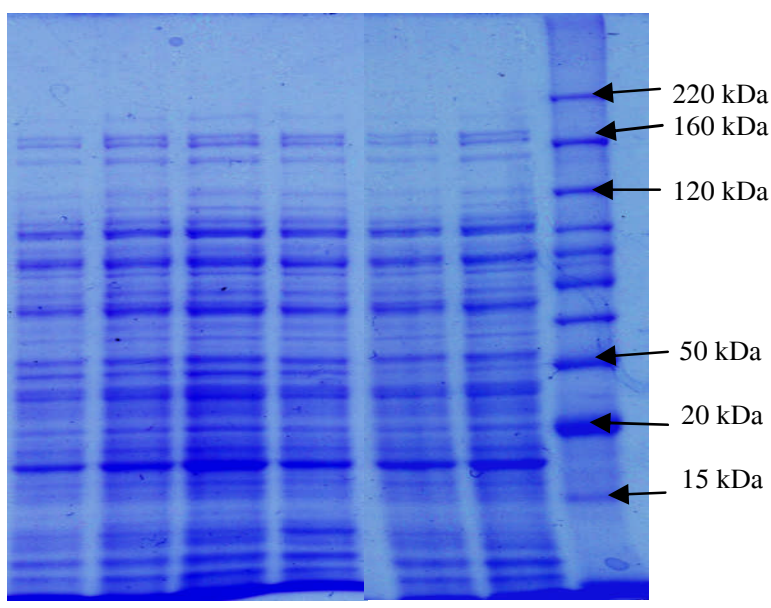

Gambar 3. Profil protein E. coli hasil iradiasi sinar gamma ( $\mathrm{K}=$ kontrol positif $0 \mathrm{~Gy}, \mathrm{M}=$ marker)

Berdasarkan hasil elektroforesis protein isolat E. coli yang diirradiasi hingga dosis 1000 Gy terlihat bahwa iradiasi gamma tidak menyebabkan kerusakan protein yang signifikan. Hal ini terlihat dari munculnya pita-pita protein dengan pola yang relatif tidak berbeda pada kisaran bobot molekul $15-220$ kDa. Demikian juga dengan hasil analisa Lab Image yang menunjukkan nilai signifikansi 0,996 atau 99,6\% data menunjukkan tidak ada perbedaan yang signifikan (Ho ditolak). Dengan demikian inaktivasi bakteri E.coli melalui irradiasi sinar gamma pada dosis di bawah 1000 Gy berpotensi besar dalam pembuatan vaksin, dimana keuntungan vaksin ini adalah memberikan imunitas humoral yang tinggi bila booster diberikan, tidak menyebabkan mutasi atau reversion (Ramamoorthy, S., 2006), dapat digunakan untuk pasien immuno-defisiensi, cocok digunakan untuk daerah tropis tetapi vaksin jenis ini membutuhkan biaya yang lebih tinggi karena membutuhkan booster (Gafar A., 2006).

\section{KESIMPULAN}

Iradiasi sinar gamma hingga dosis 1000 Gy mampu menginaktivasi sel bakteri E.coli dengan komposisi dan profil protein yang tidak mengalami perubahan yang signifikan (Signifikansi 0,996).

\section{DAFTAR PUSTAKA}

1. Arifin, M., (2006), Pengaruh Vaksin Radiasi Fascioliosis Terhadap Ternak Ruminansia, Jurnal Gakuryoku Vol. II, Bogor.

2. Benneth, C., Thatcher, S., TolmanHulsberg, J., Powers, M., Milwardm H., Nielsen, D., And Teng, D.H.F., (2002), Comparison Of Gamma-Irradiated And Triazol-Treated RNA Viruses Using The Joint Biological Agent Identification And Diagnostic, Idaho Technology Inc., Salt Lake City, UT.

3. Gaffar, A., (2006), Parasitology : Blood And Tissue, Download From : Http://Www.Med.Sc.Edu:85/Parasitology Blood-Proto.Html, University Of South California.

4. Gibco Invitrogen Corporation, (2000), Effectiveness Of Inactivation By Gamma Irradiation For Powder Trypsin Products, Grand Island, USA.

5. Hall, E.J., (1994), Radiobiology For The Radiobiologist, Lippincott Williams And Walkin, Philadelphia, 
6. Hames, B.D., (1998), Gel Electrophoresis of Proteins, Oxford University Press., New York, USA.

7. Ikmalia, (2008), Skripsi Sarjana Kimia, Program Studi Kimia, Fakultas Sains dan Teknologi, UIN Syarif Hidayatullah Jakarta.

8. Machi, S., (2002), Nuclear Techniques Serve Mankind, Japan Atomic Industrial Forum (JAIF), Inc.

9. Murray P. Deuctscher, (1990), Methods in Enzymology Vol. 182, Guide to Protein Purification, Academic Press, Inc., San Diego, California, USA.

10. Ramamoorthy, S., Lindsay, D.S., Schurig, G, Boyle, S.M., Duncan,R.B., Vemulapalli,R., And Srirangathan, S., (2006), Vaccination With GammaIrradiated Neospora Caninum Tachyzoites Protects Mice Against Acute Challenge With N.Caninum, J. Eukaryot. Microbiol. 53(2); 151-156.

11. Ruegg, P., D.V.M., M.P.V.M., (2001), Evaluating the Effectiveness of Mastitis
Vaccines, University of Misconsin Madison Square, USA.

12. Sanakayala, N., Sokolovska, A., Gulain, J., Hogenesch, H., Sriranganthan, N., Boyle, S, Schurig, G., And Vemulapalli,R., (2005), Induction Of Antigen-Specific Thl-Type Immune Responses By Gamma-Irradiated Recombinant Brucella Abortus Rb51., Clinical And Diagnostic Laboratory Immunology, American Society For Microbiology.

13. Smith, N.C., (1992), Concepts And Strategies For Anti-Parasite Immunoprophylaxis And Therapy, Int. J. For Parasite 22; 1047.

14. Tetriana, D., Sugoro, I., (2007), Aplikasi Teknik Nuklir dalam Bidang Vaksin, Pusat Aplikasi Teknologi Isotop dan Radiasi (PATIR) BATAN.

15. Vuckovic, M., et. al., (2005), GammaRadiation Induced Damage of Protein In The Thick Fraction of Egg White, Vinca Institute of Nuclear Sciences Serbia and Montenegro JSCS-3365. UDC 54-78. 